\title{
КОНЦЕПТ "ВІЙНА" \\ В ІНДИВІДУАЛЬНО-АВТОРСЬКІЙ КАРТИНІ СВІТУ ОКСАНИ ЗАБУЖКО (НА МАТЕРІАЛІ ЗБІРКИ „І ЗНОВ Я ВЛІЗАЮ В ТАНК...”)
}

\author{
ОЛЕНА ГОМЕНЮК \\ Університет імені Адама Міцкевича, Познань - Польща \\ gomeniuk.olena@gmail.com
}

KONCEPT "WOJNA"W AUTORSKIM

OBRAZIE ŚWIATA OKSANY ZABUŻKO

(NA PRZYKŁADZIE ZBIORU ,, I ZNOWU WŁAŻE DO CZOLGU...”)

\author{
OLENA GOMENIUK \\ Uniwersytet imienia Adama Mickiewicza, Poznań — Polska
}

STRESZCZENIE. W artykule przedstawiono analizę konceptu "wojna” w autorskim obrazie świata znanej ukraińskiej pisarki, poetki i eseistki Oksany Zabużko. Analizy dokonano na przykładzie zbioru utworów publicystycznych ,,I znowu włażę do czołgu... ”, który został poświęcony wydarzeniom Rewolucji Godności oraz wojnie, toczącej się na Ukrainie od 2014 roku. Scharakteryzowano główne werbalizatory konceptu oraz jego semantykę, która obejmuje przede wszystkim znaczenia autorskie.

\author{
CONCEPT “WAR” IN THE INDIVIDUAL AUTHOR PICTURE \\ OF THE WORLD BY OKSANA ZABUZHKO \\ (BASED ON THE NON-FICTION „I ENTER THE TANK AGAIN...”) \\ OLENA GOMENIUK \\ Adam Mickiewicz University, Poznan — Poland
}

ABSTRACT. The article is dedicated to the analysis of the concept "war" in the individual author picture of the world by a known Ukrainian novelist, poet and essayist Oksana Zabuzhko. The analysis was based on the example of the book ,,I enter the tank again...”, which was dedicated to the events of "Revolution of Dignity" and war, that has been lasting since 2014 in Ukraine. There have been traced the main concept verbalizers, its semantics has been clarified, they mostly contain writer meanings.

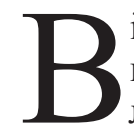

ід давніх часів проблема осмислення та розуміння війни була й залишається актуальною для людства. Практично кожна галузь науки про людину й суспільство (філософія, психологія, соціологія, історія, політологія, теологія тощо) торкається цієї теми, намагаючись установити причини іiї виникнення, розробляючи механізми попередження та протидії, оцінюючи iiï позитивні та негативні аспекти. Особливої значущості вона набуває в XX ст. після того, як світ пережив дві світові війни і в передчутті глобальної катастрофи почав замислюватися над своїм майбутнім. Не менш важливою тема залишається й у XXI ст., коли практично на кожному континенті тривають збройні конфлікти. 
Неодноразово концепт “війна” був об'єктом наукових лінгвістичних розвідок, проте досі він залишається в центрі уваги дослідників. Така зацікавленість зумовлена відмінними інтерпретаціями цього поняття в різних національних та індивідуально-авторських картинах світу, а також у контексті різних історичних періодів. Це підтверджують праці як іноземних, так і вітчизняних лінгвістів, зокрема Дж. Андерхіла, С. Богдан, Л. Брославської, Л. Венедиктової, В. Сфименка, О. Колесника, В. Крячка, Дж. Лакоффа, С. Рєзніка, Г. Яворської та ін.

Мета запропонованої розвідки полягає в тому, щоб з'ясувати специфіку об'єктивації концепту “війна" у творчості О. Забужко, зокрема на матеріалі збірки ,„ І знов я влізаю в танк...”. Як стверджує В. Кононенко, пропущені через мовну практику митця концепти ,здебільшого суттєво розширюють межі свого смислового потенціалу”, „здобуваючи все нові й нові нашарування, поповнюючи фіксовані значення”, унаслідок „смисл концепту стає мінливим, перемінним у своїх реалізаціях, таким, що часом допускає неоднозначні тлумачення"1.

О. Забужко з перших днів Революції Гідності та війни на Донбасі активно висловлює свою позицію стосовно ситуації, що відбувається в українському суспільстві. Цій проблематиці присвячена збірка її публіцистики „І Ізнов я влізаю в танк..." (вибрані тексти 2012-2016: статті, есе, інтерв'ю, спогади). Зазначена авторка стверджує, що це книга про війну. Порівн.: Тільки не про ту, залізом і кров'ю, щзо з зими 2014-го прийшла на нашу землю, - а про ту, куди менш видиму оку мирного обивателя, котра ту першу вигодувала, подібно як гнійні мікроби, потрапивши в організм, “вигодовують” йому абсиес, - $і$ котрої, на відміну від тої першої, ніхто не збирається згортати, тож мусимо вчитися в ній жити - з повною свідомістю того, що по нас увесь час "стріляють" невидимими кулями ${ }^{2}$.

Основним вербалізатором досліджуваного концепту в публіцистиці О. Забужко є лексема війна, порівн.: У мене за ию війну нагромадилася власна багата історія спроб діалогу з європейськими політичними елітами, колись опишу в мемуарах (с. 163). У словнику подано два значення цього слова: „1. Організована збройна боротьба між державами, суспільними класами тощо. 2. перен. Стан ворожнечі між ким-небудь; суперечка, сварка з кимось; боротьба"з. Натомість у досліджуваних текстах актуалізується передусім першийлексико-семантичний варіант: Щойно в ході російсько-української війни заскочена Свропа відкрила в себе під боком ию визрілу, як пухлина, трандіозну “постмодерністську диктаmуру"... (с. 392).

Водночас до ядра номінативного поля концепту “війна" належать лексеми інформвійна (інформаційна війна), воєнні (бойові) дії, фронт, битва, воювати, конфлікт, напр.: Я вже можу мемуари писати з того всього, що було пережито за иеей час, і якими хвилями вся ияя інформвійна йшла (с. 195). Периферію формують номени кібервійна, визвольні змагання, АТО, армія, боротьба, атака, передова, боєць, воєнний / -a, / -е, військо, вторгнення тощо. До речі, вербалізатор $A T O$ в тексті збірки вжито лише раз: Можна багато розводитися над тим, чому ия технологія не спращювала і воювати в АТО украӥнці, всу-

${ }^{1}$ В. I. Кон он ен ко, Смислова структура кониепту, [в:] Семантика мови і тексту, матер. IX Міжнар. наук.-практ. конф., Івано-Франківськ 2006, с. 248.

${ }^{2}$ О. З З а бу ж ко , ,І знов я влізаю в танк...”. Вибрані тексти 2012-2016: Статті, есе, інтерв’ю, спогади, Київ 2016, с. 11 - далі подаємо поклики на це видання в круглих дужках, зазначаючи конкретну сторінку.

${ }^{3}$ Словник украйнської мови, в 11 томах, ред. колег. І. К. Білодід (голова), П. Й. Го рець к й та ін., Київ 1970-1980, т. 1, с. 669. 
Кониепт “війна” в індивідуально-авторській картині світу Оксани Забужко (на матеріалі збірки „І знов я влізаю в танк...”)

переч усій тій інформаційній “колаборащії”, пішли таки “як за своє”... люди пішли воювати за свою землю - ту саму, за яку віки тому воювали їхні пращури (с. 410). Це демонструє позицію письменниці називати ситуацію на сході України війною із сусідньою держаною, а не антитерористичною операцією чи збройним конфліктом. Наголосимо, що в міжнародному публічному праві поняття “війна” вживається „для позначення збройного протистояння між двома або декількома суверенними суб'єктами міжнародного права, якими можуть бути виключно держави. У випадках, коли відбувається громадянська війна чи коли якийсь народ або нація бореться за незалежність, потрібно застосовувати термін «збройний конфлікт»"4.

Не менш розгалуженою в досліджуваному концепті є семантична структура, що об'єктивує передусім індивідуально-авторські смисли. Уже на перших сторінках збірки О. Забужко зосереджує увагу читача на інформаційній війні, що велася й ведеться Росією проти України: Ї̈̈ звуть “інформаційною”, “психологічною”, “гібридною” та ще десятками протеївських псевдонімів i тим часто-густо применшують їі істинний масштаб $i$ значення, так, буиім вона є чимсь на киталт докладки до “головної, “гарячої”, тод $i$ як в дійсності справа стоїть якраз навпаки... (с. 11). Ця форма протистояння була відома ще в Стародавньому світі й почала широко використовуватися у 80-х роках XX ст., проте зі стрімким розвитком інформаційних технологій, зокрема Інтернету, набуває все більшого значення. Сьогодні легко можна поширити неправдиву, провокаційну, “потрібну” інформацію з метою маніпуляції та формування необхідної суспільної думки, на що звертає увагу й письменниця: Паралельно весь изей час у цеентральних ЗМІ накручувався мем “двох Україн”, “проросійського Донбасу” і т. д. - словом інформвійна “за Новоросію” велася системно і по-спецслужбівському професійно - килимовою атакою (с. 241242) або Авжеж, ту багатолітню “повзучу” інформвійну, яка передувала нинішній воєнній агресї, Україна програла Путінській імперї “за неявкою”... (c. 245).

Наведені контексти експлікують у структурі концепту “війна” смисли “та, що ведеться інформаційною зброєю”, “та, що була програна через бездіяльність”. Авторка також уважає, що одним з методів ведення цієї війни є тролінг (розміщення в Інтернеті провокаційних повідомлень 3 метою викликати флейм, конфлікти між учасниками, образи, війну редагувань, марнослів'я тощо ${ }^{5}$ ): Головний спосіб ведення иієї війни - безпрецеедентний, сюрреалістичний за масштабом мега-тролінг, де на позір, не існує способу відділити справжнє від фейкового й “приземлити” дедалі більше “сповзаючу в віртуал” циивілізаційну “cmpixy” на трунт здорового глузду... (с. 119), що знайшло відображення в концептуальному смислі “та, що не дозволяє відрізнити правду від брехні”.

Зазвичай інформаційна війна ведеться в поєднанні з психологічною, що має на меті змінити в потрібному напрямку психологічні характеристики (погляди, настрої, ціннісні орієнтації і под.) людини. Це демонструють концептуальні смисли “та, що ведеться у свідомості людей”, “яка бореться за смисли”, порівн.: А от спецслужби - ие те єдине, чим Росія і справді сильна. Під їхні методи всю июю війну вибудовано. Вони справді перейшли на “війну в головах” (с. 156); ... війна ведеться не тільки й не скільки за території, скільки за смисли і завдання російської ідеократї ("кремлівської матриці"” за П. Померанцевим) є вже не

\footnotetext{
${ }^{4}$ Міжнародне публічне право, підруч., за ред. В . М. Ре пе ць кого, Київ 2012.

${ }^{5}$ Словотвір, [в:] Електронний ресурс: http://slovotvir.org.ua/words/trolinh (20.02.2017).
} 
створити “альтернативну картину світу”, а внеможливити існування такої картини взагалі... (с. 343).

Інформаційна, психологічна й економічна війни є типовими методами ведення "гібридної війни", що має на меті досягнення державою-агресором політичних цілей шляхом дестабілізації ситуації в державі, проти якої спрямована агресія. Сторона-агресор зазвичай не зізнається в таких діяннях та всіляко намагається приховати свою причетність до ситуації, що склалася. Російськоукраїнську війну, що сьогодні триває, також часто називають “гібридною”, що й відображено в аналізованій публіцистиці, порівн.: Коли відкрити архіви й уважно вивчити історію..., стане зрозуміло, щзо нічого принцииово нового в иій так званій “гібридній війні” насправді немає. Змінились лище масштаб i технологіï (с. 151). Тут об'єктивуються такі смисли: “та, що є гібридною”, “яка немає принципових відмінностей”, „яка відрізняється лише масштабом і методами".

О. Забужко виокремлює ще один тип війни — "війна телебачення 3 книгою”, порівн.: Можливо, цее взагалі війна Книжки з Телевізором. Можливо, колись історики так про неї напишуть - коли ми ї̈ виграємо (с. 63). Телебачення має великий вплив на формування громадської думки: легко та вміло маніпулює фактами, подає інформацію вже з їі оцінкою, досягаючи потрібної замовнику (власнику) мети. Книга натомість дає змогу читачеві самостійно оцінити персонажів та ситуацію, сформувати свою думку та позицію. Цене вогнепальназброя, але часто буває підзабороною, вилучається, знищується

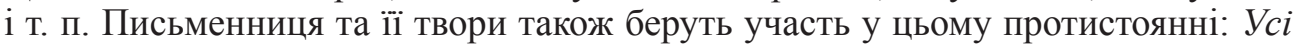
ųi 20 років моя книжка [Польові дослідження з українського сексу] була “на війні" (і хоч-не-хоч, — я разом з нею) (с. 383) або “Війна” ФСБ з цим романом [Музей покинутих секретів] - аж до вилучення його спецназом ФСБ під час обшуку в директорки Украӥнської бібліотеки в Москві в жовтні 2015 р., є так само не випадкова... (с. 18).

Уживаючи присвійні займенники, зазначена авторка вербалізує категорію інтимізації та надає війні персонального характеру. Це експлікується у смислах “та, що є в кожної людини” (Війна є війна, і в кожного вона своя (с. 193); Можна сказати, щзо ие історія моєї персональної війни - досі не конче видимої чи врозумливої українському читачеві (с. 19)), “яку потрібно в собі відчути" (...коли розумієи масштаб загрози, мовчання означає солідарність з убивиями. Власне з моменту, коли починаєш так відуувати, ие й є твоя війна, все решmа - або колаборація, або дезертирство (с. 19)), “яка є частиною війни моєї країни" (А можна, трохи перефразувати класика і сказати, щуо "історія моєї війни є частиною історії війни моєї батьківщини” (с. 21)).

Безперечно, у центрі уваги О. Забужко війна на Донбасі, але письменниця неодноразово згадує про ситуацію України в ХХ ст., зокрема під час Першої та Другої світових воєн, а також “холодної війни”, порівн.: ...тільки за минуле століття Україна принаймні тричі “була в Лефортово” - після Перших визвольних змагань (вся), після 1932-34 рр. (Наддніпрянська) $i$ після Другої світової війни (вся)... (с. 405); ...обидві країни [Польща і Україна] отримали на голову потужний вплив інформачійного багна, замішаного, з одного боку, на міфах доби “холодної війни”, щзо були накривали весь “східний блок” одною нерозрізняльною плямою, а з другого - на елементарному невігластві та природному людському страхові перед усім невідомим (с. 361-362). Обидва наведені приклади засвідчують складну ситуацію країни в минулому столітті та дають 
Концепт “війна” в індивідуально-авторській картині світу Оксани Забужко (на матеріалі збірки „І знов я влізаю в танк...”)

змогу виокремити в структурі концепту “війна” такі семантичні фрагменти, як: “та, що нагадує місце катування”, “та, що поширює неправдиву інформацію”.

Погоджуємося 3 твердженням Г. Яворської, що в українському дискурсі концепт "війна" має динамічну структуру6. Це засвідчують в аналізованих текстах вирази до війни та перед війною, що передусім уживалися для позначення життя до початку Другої світової війни, а 32014 року для українців набули іншого значення - “до війни з Росією на Сході України”. Напр.: Якщзо в довоєнному Донецьку публіка збиралась - на літературний вечір ("встреча с писателем” сама по собі була подією, нечастою в міському пейзажі!), то в Дніпропетровську, щуо до війни, щуо нині, - саме “на украӥнський захід”, нарочито, як на політичну маніфестацію... (с. 217); ... у мене від поӥздки на Донбас незадовго перед війною враження від спілкування з тамтешнім свяшзенством лишилися, прямо скажу, моторошнуваті (с. 152). Наведені контексти об'єктивують концептуальний смисл — “та, що є вихідною точкою відліку часу".

О. Забужко нагадує нам, що ще наприкінці XIX ст. українські мислителі закликали остерігатися Москви: Один з найвизначніших наших мислителів модерної доби, Михайло Драгоманов, прозираючи на століття попереду, у кіниі 19-го, після всіх російсько-турецьких воєн, тлумачив нетерплячим сучасникам - щзойно тепер, коли впоралися з Османською імперією, Москва стає нашою проблемою номер один (с. 161). Війни, які вела Росія проти інших країн у різні періоди, частково пояснюють сьогоднішню агресію проти України, напр., грузинська війна: У 2008 р. грузинська війна і реакція на неї Заходу показала Путіну, щзо двері в Україну стоять перед ним відчинені (с. 187) (семантичний фрагмент “та, що передує іншим війнам”). Ялова реакція окремих країн Євросоюзу на події як у Грузії, так і в Україні дозволяє Російській Федерації і надалі дестабілізувати ситуацію в пострадянських державах. Авторка вбачає в цій агресії не лише бажання втримати вплив над колишніми республіками, а й значно більшу загрозу — бажання заволодіти всім світом: ... ияя війна - Beлика Холодна війна Росії за “світове панування” методом проникнення й розкладання усіх краӥн “з середини” - насправді зовсім не припинилася із “розпуском” СРСР у 1991-му, а тривала всі ці двадиять з гаком років... (с. 204) (семантичний фрагмент “та, що є прихованою і загрожує всьому світові”).

Намагання українців зберегти свою ідентичність і протистояти Росії реалізується в таких концептуальних смислах: “та, якій намагаються протидіяти”, “та, винуватці якої не покарані”": ...нація в изей час... чесно штурмувала військомати: в ті перші дні березня вони, нагадую, були переповнені чоловіками призовного віку, щзо приходили “зголошуватися на війну”... (с. 407); ...за сто літ невгамовної, то “гарячої”, то “холодної” війни на знищення - на стирання України з мапи світу й пам'яти людства - жодний винний на лаву підсудних не сів і за скоєні проти украӥнців злочини не відповів... (с. 355). Однак письменниця вбачає й позитивні аспекти, що репрезентують у структурі концепту “війна" такі семантичні складники, як: “та, що повертає тожсамість народу”, “та, метою якої є незалежність держави”, “та, що відкриває нові горизонти", напр.: Схоже на те, щзо повертаючи собі свою тожсамість у війні за незалежність, украӥнці вперше побачили, як багато вони мають розказати світові (с. 214).

${ }^{6}$ Г. Я в орс ька, Кониепт “війна”: семантика і прагматика, [в:] „Стратегічні пріоритети”, гол. ред. В . П. Горбулі н, Київ 2016, № 1 (38), с. 22. 
Після розпаду СРСР у засобах масової інформацій поширювалася думка, що незалежність Україна отримала в подарунок, що суспільство не було до цього готове, що не було сформованої еліти, яка б повела країну. Проте цей міф швидко розвіяла війна: ...багатолітній, із російських 3 МІ перейнятий мем, буиім "незалежність нам дісталась задурно”, теж можна віднести до скасованих війною: за те, що "дістається задурно”, на смерть не стоять! (с. 405). Вона також зруйнувала багато стереотипів щодо поділу країни на проросійську та проєвропейську, щодо дружніх стосунків України з Росією.

У 2014 році, беручи активну участь у міжнародних форумах, О. Забужко намагалася пояснити, що відбувається в Україні, напр.: Був період, коли в Європі справді не розуміли, що це за війна така на нас звалилася (с. 193). Російські медіа й політики переконували Захід, що це внутрішній конфлікт, що в країні триває громадянська війна: Роками росіяни їх [європейців] готували до зовсім іншого сиенарію - що Украӥна нібито розколота на "проросійську" $i$ "прозахідну", які між собою непримиренно ворогують, і що вона сама собою розпадеться... Першим Майдан похитнув цей стереотип, а потім, коли "русская вєсна" показала, що вся ия міфічна "половина Украӥни з російськомовним населенням”, яку готували до відколу, раптом бере в руки зброю і починає воювати проти Росії, в яку нібито так сильно хотіла, то на Заході справді якийсь час не знали, чому вірити (с. 193-194). Тому в структурі аналізованого концепту виокремлюємо позитивно маркований смисл “та, що руйнує стереотипи”.

Згадуючи перші дні протистояння та евакуацію з Луганська В. Голобородька, письменниця пише про неготовність країни та державних структур до війни, порівн.: ...иілкковита функиіональна неспроможність інституцій $і$ локальна “точкова" ефективність волонтерських горизонтальних зв'язків (с. 239); Одне слово - до нинішньої війни ми виявилися драматично неготові (с. 14). Проте О. Забужко не втрачає оптимізму й переконана, що український народ переможе в цьому протистоянні: Як надія для всього людства: ми виграємо ицю війну. Не можемо не виграти (с. 412). Наведені контексти демонструють об'єктивацію таких смислових фрагментів, як: “та, до якої Україна не була готова”, “та, яку ми виграємо".

Отже, концепт “війна" в індивідуально-авторській картині світу О. Забужко має розгалужене номінативне поле та об'єднує в семантичній структурі передусім авторські уявлення, які експлікуються в смислах, що є позитивно і негативно маркованими, та мають подекуди протилежні значення (порівн.: “та, що була програна” і “та, яку ми виграємо”).

Перспективність дослідження вбачаємо в аналізі концепту “війна" в індивідуально-авторських картинах світу інших українських письменників, зокрема представників Донеччини та Луганщини, які безпосередньо на собі відчули всю трагічність бойових дій, що досі тривають. Це дасть змогу змоделювати концептуалізований образ війни в сьогочасній мовно-національній картині світу українців. 